\title{
Profiling the Characteristics of Karu Slum, Nasarawa State, Nigeria
}

\author{
Ezeamaka Cyril Kanayochukwu'1, Bala Dogo ${ }^{2}$ \\ ${ }^{1}$ Department of Geography, Nigerian Defence Academy, Kaduna, Nigeria \\ ${ }^{2}$ Department of Geography, Kaduna State University, Kaduna, Nigeria \\ Email: cyrilezeamaka@gmail.com
}

How to cite this paper: Kanayochukwu, E.C. and Dogo, B. (2019) Profiling the Characteristics of Karu Slum, Nasarawa State, Nigeria. Journal of Service Science and Management, 12, 605-619.

https://doi.org/10.4236/jssm.2019.125041

Received: April 16, 2019

Accepted: August 10, 2019

Published: August 13, 2019

Copyright $\odot 2019$ by author(s) and Scientific Research Publishing Inc. This work is licensed under the Creative Commons Attribution International License (CC BY 4.0).

http://creativecommons.org/licenses/by/4.0/

\begin{abstract}
The study provides comprehensive empirical information on the magnitude and characteristics of slums in New Karu District of Karu LGA in Nassarawa State. The proximity of New Karu to FCT, Abuja has made it a very important settlement and a gateway to the Capital of Nigeria. 5 of the 12 wards of New Karu were studied. Direct Field observation and interview were used to obtain information of the study area. This study used a systematic random sampling method using the interval of five (5) households. 500 questionnaires were administered to the selected household heads. The study revealed that the houses are built from mud (47\%) wood (15\%), Zinc (16\%) and Brick/block (22\%). Further probe revealed that 35\% agreed that the rents are affordable while $65 \%$ disagreed. $13 \%$ of the houses do not have any form of toilet, thus the occupants defecate in the nearby open bushes. The result also revealed that $90 \%$ of the households are connected to public electricity and $10 \%$ are not. The survey further revealed that $45 \%$ of the respondents dump waste into the gutters around them houses and 55\% dump at a common waste point. This study has shown that the basic social facilities needed to making life better do not exist in New Karu District. Therefore, Karu LGA and Nassarawa State Government should provide the infrastructures and facilities required to improve the well being of the residents of New Karu. The findings of this study confirmed that there exist high levels of inadequacies of infrastructure causes the environmental and living conditions.
\end{abstract}

\section{Keywords}

Slum, Profiling, Population, Abuja, FCT, Housing, and Development

\section{Introduction}

The Karu slums profiling consists of an accelerated, action-oriented assessment 
of urban conditions, focusing on priority needs, capacity gaps, and existing institutional responses at local and national level [1]. Cities in developing countries have been witnessing rapid and spontaneous growth resulting in a myriad of problems. The menace of urban sprawl and deteriorating environment, housing shortages, unemployment and other socio-economic and environmental problems has made new thinking and approaches to solving them [2]. With half of the world's population already living in urban areas, the challenges we face in the battle against urban poverty, the quest for cities without slums, cities where women and children feel safer, for inclusive cities with power, water and sanitation, and affordable transport, for better planned cities and for cleaner, greener cities daunting [1].

Informal settlements are a common feature of developing countries in sub-Saharan Africa, with rapidly urbanizing area, and almost all of this growth has been in slums, where new city residents face overcrowding, inadequate housing and a severe lack of water and sanitation [3]. Housing remains a major problem for most people especially in developing nations such as Nigeria has led to an extensive development of squatter or unplanned settlement [4]. UN-Habitat (2003) studies indicated that about $70 \%$ of the urban population lived in unplanned settlements and that about $60 \%$ of the urban housing stocks are to be found in these settlements.

In context of urban settlement typologies, informal settlement falls under the category of irregular settlements. Such settlements are referred to by some aid and development organizations as areas where development (spatial expansion) and occupancy are not in compliance with legal, urban and environmental standards set by public authorities [5]. Slums are symptoms of immigration as a movement from rural to urban areas in the industrialization period. While this action was realized long before in developed countries, it is still a continuing process in developing countries [6]. A range of problems has arisen in these slum areas. These slums have no basic technical and social infrastructures and led to visual and physical contamination. Slums are neglected parts of cities where housing and living conditions are lacking. There is a range of shelter types in Karu, from solidly built concrete and aluminium structures to makeshift zinc or mud-based buildings with inadequate roofing. The favoured type is commonly found in planned neighbourhoods and often likely in unplanned neighbourhoods, where new building plans are not subject to official approval. Improving the quality of shelter and promoting good planning methods are major challenges for Karu [7].

There are at least seven neighbourhoods in Karu that could be considered slum areas; these are Mararaba, One-man Village, Ado, New Nyanya, Nyanya Gwandara, Masaka. These slums are characterized by poorly built housing, inadequate water, waste, sanitation and electricity facilities cramped living conditions exposure to pollution and insecure property rights. Slum-dwellers in Karu deserve better living conditions [8]. Slums range from high density, squalid central city tenements without legal recognition or rights, sprawling at the edge of 
cities. Access to urban land for housing has been a major issue for the vast majority of poor families in most developing countries in the last decades. Most recently, the issues related to access to urban lands are more acute, especially because serviced land became a highly disputed commodity in the markets. The world population is 7.7 billion [9] and more than $50 \%$ of the global populations live in cities and over $32 \%$ of urban dwellers live in slums [10].

The creation the new Federal Capital for Nigeria in 1978 and consequence movement of seat of power from Lagos to Abuja in 1991, has led to uncontrolled and rapid expansion. Which has exceeded the anticipated master plan of Abuja [11] [12], with resultant evolution of suburbs which are characterized by unplanned growth in property (housing) resulting from absence of development control. Karu began to swell with an uncontrolled influx of people as early as in the mid-90s barely five years after the seat of government officially moved from Lagos to Abuja. Construction activities which broke ground in Abuja with the expansion of government and private businesses heighten demand for affordable accommodation by construction workers and other low-income working-class people [13]. Studies by scholar others have shown that there are issues and problems associated with the rapid pace of urbanization of Abuja that created slums in Karu and other settlement outside the city [1] [2] [7] [8] [10] [13] [14]. The close in proximity of Karu to the Federal Capital Territory (FCT), Abuja has made Karu home to many [15]. These slums have become the most complicated problem in our cities. Some of the worst slums in the neighbouring states of FCT are found in Karu Local Government Area of Nassarawa State. People living in slums need certain essential services. They are an important part of our city life. The continuing expansion of these largely unplanned settlements, currently without adequate water supply, good sanitation, drainage, waste management, electricity and good access among others, has led to a further decline in the welfare and standard living for the inhabitants [1] [7] [13]. The proximity of New Karu to FCT, Abuja has made it a very important settlement and a gateway to the Capital of Nigeria, the giant of Africa. There are negative consequences accompanying such a relationship. Therefore, the pursuit of a well-articulated profiling of the slum settlements in New Karu resulting from this relationship would engender improving the working and living conditions in New Karu.

The aim of the study is to provide comprehensive empirical information on the magnitude and characteristics of slums in New Karu. This paper was borne out of the dire need of providing answers to the identified problems of informal settlements. This study will address questions such as how many slum settlements are there in New Karu? When and how did they emerge? What are the manifestations of slums in New Karu? What are the environmental consequences/implication slums in New Karu? The findings of this study would be of special interest to FCTA, Local Government administrators, urban planners and City managers', policy and decision makers. It will provide baseline information useful in designing appropriate strategies for dealing with problem of slums. It will also assist government and non-governmental organizations (NGOs) (both 
local and international) in their quest to make improve the living conditions of poor people in such slums. This study is an attempt to profile the slum settlements in New Karu, such a study would facilitate positive ways of solving the problems of slums in New Karu. The findings will confirm whether the level of inadequacies of infrastructure causes the environmental and living conditions in the slum. The study is limited to New Karu and the article is organized as follows, introduction, which deals with the background, aim and objectives of the paper, The study area, method, result, conclusion.

\section{Literature Review}

The word "slum" is often used to describe informal settlements within cities that have inadequate housing and squalid, miserable living conditions. They are often overcrowded, with many people crammed into very small living spaces. These settlements lack basic municipal services such as water, sanitation, waste collection, storm drainage, street lighting, paved sidewalks and roads for emergency access [1]. Most slums do not have easy access to schools, hospitals or public places for the community to gather. Many slums have been serviced and unrecognized for long period. Like all informal settlements, housing in slum is built on land that occupants do not have legal claims to and without any urban planning or adherence to zoning regulations. In addition, slums are often areas where many social indicators are on a downward slide, for example, crime and unemployment are on the rise. All slums are not same, and some provide better living condition than others. Likewise, slum dwellers are not a homogeneous population, but a diverse group of people with different interests, means and backgrounds. Slums are also a significant economic force. In many cities, as much as 60 per cent of employment is in the informal sector of the urban population [1]. Today, more than one billion people in the world live in slums. In the developing world, one out of every three people living in cities lives in a slum. A slum is defined as household of a group of individuals living under the same roof in an urban area who lack one or more of the following [3]: Durable housing of a permanent nature that protects against extreme climate conditions; sufficient living space, which means not more than three people sharing the same room; Easy access to safe water at affordable price; access to adequate sanitation in the form of a private or public toilet share by a reasonable number of people; and security of tenure that prevents forced evictions.

Cities in developing countries are known for their informal delivery of housing for low-income groups. Informal housing slums, temporary settlements, are very common features of all the urban landscapes in any developing country. Housing is described as informal when it does not conform to the laws and regulatory frameworks set up in the environment in which it occurs [3]. It can be informal at several levels. Slums are generally the only type of settlement accessible to the poor in cities, where competition for land and motivation for profits intense. There are two main reasons why slums develop: population growth and governance. Rapid urban population growth, the urbanization of 
poverty and the proliferation of slums are being driven to great extent by this dynamic form of globalization. At the same time, globalization also drives economic and cultural growth and natural population growth continues to occur. Today, more than one half the world's population resides in urban areas. More than 90 percent of this urban growth is taking place in the developing world [1].

The basic things a government can do to prevent new slums from developing. One is to recognize that urbanization is going to happen. Sometimes governments believe that adopting alternative policies, such as focusing on rural development, will stop urbanization. This approach is rarely effective [7] and once governments accept the reality of urban growth, the next step is to plan for it and determine where the new residents will live. Authorities should identify land and plan for its settlement even if money is not available for urban service. Once people settle on that land and feel that they have a right to live there. Over time, the area upgrades incrementally developing country studies. The problems of housing the urban poor are mainly due to rapid urbanization, high standards, high cost of building materials, high rents, changes in economy, new means of transportation, and concentration of social amenities in urban areas [4]. Many cities having an increase in population as a result of rural-urban migration, these increase in population led to a need for more housing, housing supply could not meet demand, thus leading to the proliferation of slums [4].

Approximately two thirds of the populations of New Karu currently live in slums [7]. These uncontrolled and squatter settlements are further characterized by the following characteristics. Their births are usually due to raid urbanization, occasioning housing problem. Residents are mostly low-income families who are adventures or either migrants from a rural area or are victims of urban renewal schemes. Studies on the socio-economic situation of household living in irregular settlement indicate a strong correlation between urban poverty, tenure status, access to service and citizenship, lack of basic services and substandard housing illegal and inadequate building structures, overcrowding and high density and unhealthy living condition and hazardous location, and insecure, irregular or informal settlement developing countries, poverty and social exclusion and minimum settlement size.

\section{Study Area}

New Karu of Nasarawa State lies east of Nigeria's capital city, Abuja. Karu is the administrative headquarters of the Karu Local Government Area (LGA), one of the 13 LGAs that make up Nasarawa State. Karu Local Government was created in October 1991. Karu is close in proximity to the Federal Capital Territory of Nigeria. It has an area of $2640 \mathrm{~km}$. Karu Local Government Area has its headquarters in New Karu Town, is located in the North Central region of Nigeria. It shares boundaries with Abuja to the west, Keffi LGA of Nasarawa State to the South and Jaba LGA in Kaduna State to the North as shown in Figure 1. The proximity of the major urban settlement of Karu to Abuja makes them part of the development corridors of the Federal Capital Territory [7]. 


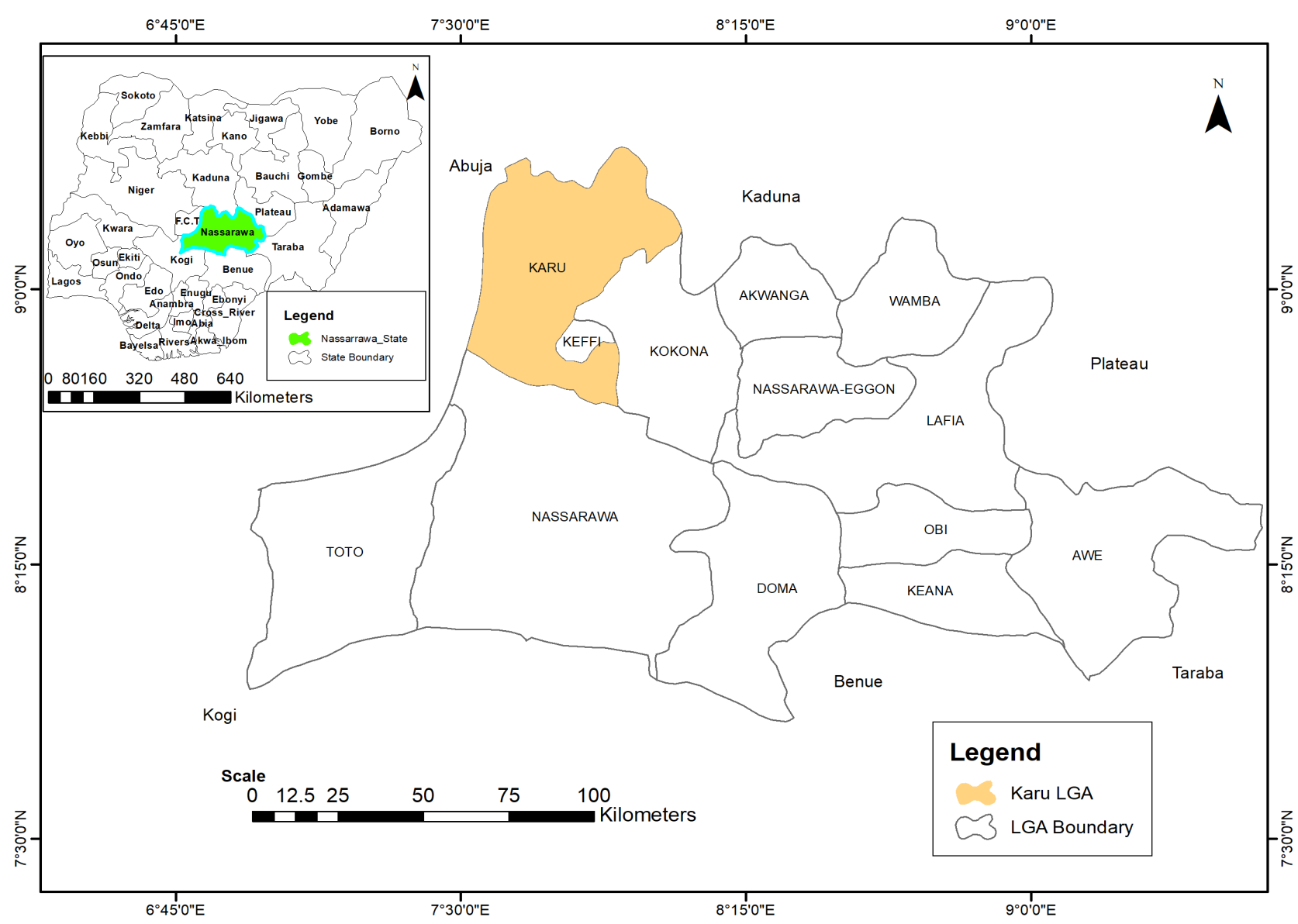

Figure 1. Karu local government area in Nassarawa State. Source: Nassarawa State Ministry of Lands and Survey (2016).

The climate of New Karu is characterized by a dry season from November to March and wet season from April to October. The duration of the raining season is between 180 days to 190 days. The average annual rainfall is $1,632 \mathrm{~mm}$, with the highest recorded in the months of July, August and September [16]. The New Karu records its highest temperature during the dry season when there is few if any cloud cover. It has an annual temperature range between $21^{\circ} \mathrm{C}$ to $32^{\circ} \mathrm{C}$. During the raining season, the maximum temperature is lower due to the dense cloud cover, diurnal annual range is also much lower, sometimes not more than $7^{\circ}$ centigrade in July and August [7]. However, Karu has two distinct seasons, wet (rainy) and dry seasons. The temperature, rainfall and humidity patterns follow closely, the pattern of two dominant tropical air masses, leading to the emergence of distinct climatic regimes

Temperature during the dry season (November-April) can be as high as $27.5^{\circ} \mathrm{C}$ and $37^{\circ} \mathrm{C}$. March is a critical month during which temperature is usually highest. The maximum temperature ranges from $23.5^{\circ} \mathrm{C}-36^{\circ} \mathrm{C}$ and is registered in the wet season (May-October). Daily range is reduced to about $7^{\circ} \mathrm{C}$ illustrating the moderating influence of cloud cover and these patterns however vary with elevation [7]. Relative Humidity during the dry season at a higher elevation is about $20 \%$ while at lower elevation it is $30 \%$. In the rainy season, it could be as 
high as $90 \%$ in the morning and $50 \%$ in the afternoon. At the valleys and plains the oppressive in terms of reduction of comfort level [7].

The start of rainy season in Karu LGA is around April [1]. The rain tapers off, very rapidly October. Thus, the duration of the rainy season is between 180days to 240 days in the year and total rainfall received during this period is between $1145.55 \mathrm{~mm}-1631.7 \mathrm{~mm}$. In Karu LGA, 60\% of the annual rainfall is in the months of July, August and September. The spatial pattern of rainfall in the study area is slightly influenced by the north-central highlands with a mean annual rainfall between $1100 \mathrm{~mm}$ to about $2000 \mathrm{~mm}$ [7]. A combination of geology and relief reveals topographic constraints value or hazard rating which is a useful index for building development and for identifying developable areas like Karu L.G.A. The geologic features in Karu are founded on basement complex structures that characterize much of the country [16]. The major formation constituting the bedrock includes the combination of different metamorphic and igneous rock formations especially migmatites and muscovite biotic schist having occasional out crop bands. The rock formation occurs in varying forms throughout the Karu Abuja region. In Karu, there exist the prevalence of network of streams and rivers many of these streams are small and seasonal. The major rivers are Rivers Ado and Uke, flows all the year round. The natural vegetation is of the park savannah type, featuring dense tropical woodland with shrubs and grasses. There is substantial wildlife population in the bushes of Karu composing grass cutters, monkeys and antelopes [7].

The population of the entire Karu Local Government Area was 216,230 people [17] as shown in Table 1. The population of Karu has been growing due to

Table 1. Population of Nassarawa state.

\begin{tabular}{ccccc}
\hline S/NO & Local Govt. Area & Male & Female & Total \\
\hline 1 & Akwanga & 56,135 & 53,767 & 111,902 \\
2 & Awe & 57,326 & 55,757 & 113,083 \\
3 & Doma & 71,395 & 67,596 & 138,991 \\
3 & Karu & 109,515 & 106,715 & 216,230 \\
4 & Keana & 40,873 & 40,928 & 81801 \\
5 & Keffi & 47,527 & 45,023 & 92,550 \\
6 & Kollona & 54,379 & 54,179 & 108,558 \\
7 & Lafia & 165,631 & 164,291 & 329,922 \\
8 & Nasarawa & 95,105 & 92,115 & 187,220 \\
10 & Nasarawa-Eggon & 74,543 & 73,862 & 148,405 \\
11 & Obi & 74,675 & 74,302 & 148,977 \\
12 & Toto & 59,675 & 59,167 & 119,051 \\
13 & Wamba & 36,813 & 35,874 & 72,687 \\
& TOTAL & 943,801 & 925,576 & $1,869,377$ \\
\hline
\end{tabular}

Source: [17]. 
migration of people from other parts of the country. In New Karu urban area as a whole, about $20 \%$ of the total population came to the area between 2000-2002 in the last 3 - 5 years, 37\% between 1996 to 1999 and $43 \%$ were resident before 1996 [18]. The original inhabitants of Karu are the Gwari, Gade, Gwadara, Gana-gana, Koro and the Bassa tribes, with a little Hausa community [1] [7]. Their main occupations are civil servants in FCT Abuja and trading in the formal and informal sectors [1]. Karu LGA is known for agriculture, being blessed with fertile soils and favourable farming conditions. As such, many inhabitants of the Karu LGA are engaged in agriculture, producing a variety of crops that are used as foodstuff and as components for making other goods. Most of this activity is done by individual farming households and small land owners, rather than larger-scale commercial farming companies. Farmers are therefore key stakeholders when it comes to local economic development issues concerning the rural areas surrounding Karu. This study covered 5 of the 12 wards of New Karu (Figure 2).

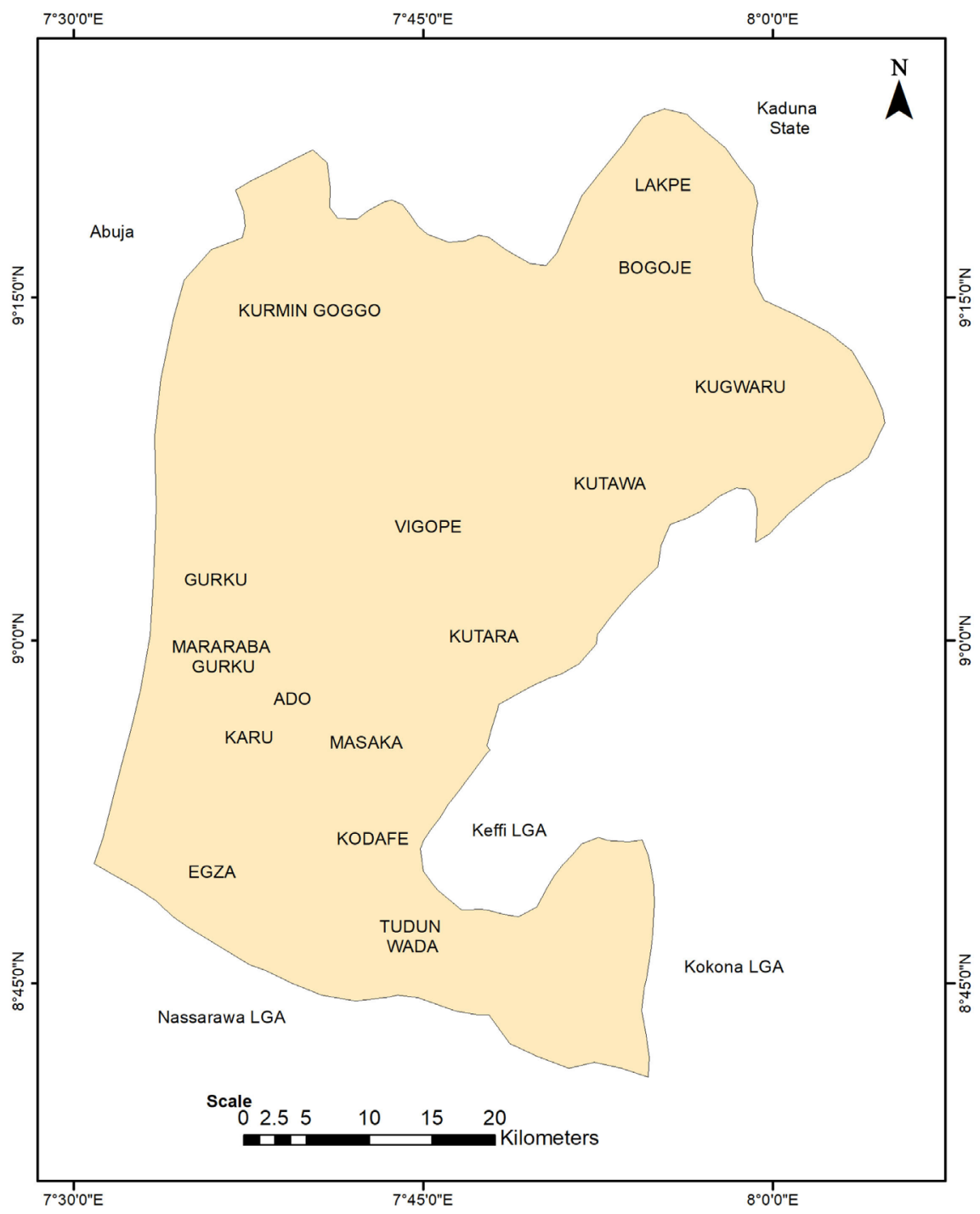

Figure 2. Administrative wards in Karu local government area. Source: [19]. 


\section{Materials and Methods}

Field observation, personal interviews and administration of questionnaires were administrated on the residents and were collected on site and directly from field surveys. These were the major bulk of the data for the study. Published and unpublished materials were also used, which includes literature from various texts, article, journals, monographs maps, digital maps, paper maps, and census figures. A set of questionnaires was directed at resident within Karu settlement. The questions were seeking to provide insight into the prevailing environmental conditions. The personal field survey gave insight into direct personal observation, which was achieved by identifying the existing condition of social facilities and the level of physical development. A pilot survey was carried out to arrive at pertinent questions

A reconnaissance survey was carried on the 10th March 2018, out to establish the boundary of the study area, the level of infrastructural development of the study area and the land use components after the reconnaissance survey. This study used the personal interview method for questionnaire administration, information about population, household size, age, sex, tribe, religion, occupational status, income level, etc. The head of households was requested to respond for each household. This study used the direct personal observation, information was collected on site regarding the availability and quality or otherwise of such infrastructure, facilities, utilities and services as housing condition, potable water supply, roads, accessibility to individual houses, drainage system and solid waste disposal and management. The questionnaires were randomly distributed t-randomly picked households using systematic sampling method. This study used systematic random sampling method using the interval of five (5) households. 500 questionnaires were administered to the selected household heads in the settlement. This study used simple statistical methods to present its findings such as charts, frequency tables, and percentage methods. The data obtained was analysed using chi-square statistical method and the study also employed the simple descriptive and inferential statistical methods.

\section{Results}

In understanding the dynamic of the relationship between man and his environment and profiling the Karu Slum, it is important to know the demographic and socio-economic profile of the settlement. The result reveals that $18.80 \%$ of the respondents are below the age of 21 to 35 years; these respondents are most likely to be students and job seekers. The result also shows that $31.20 \%$ are aged 36 to 60 years old, while $37.60 \%$ represent the ages of 61 to 75 years and $12.40 \%$ of the respondents were above 75 years of age (Table 2). The result further shows that $56.40 \%$ are male and $43.60 \%$ are female. The result reveals that majority $(46.40 \%)$ of the respondents are married and $28.80 \%$ were not married while $13.60 \%$ were widowed and $11.20 \%$ were divorced. This reveals the fact that young families inhabit the settlement. The result also reveals that $36 \%$ of the 
Table 2. Socio-demographic characteristics of household heads.

\begin{tabular}{|c|c|c|}
\hline Characteristics & Frequency & Percentage (\%) \\
\hline \multicolumn{3}{|l|}{ Age Group } \\
\hline $21-35$ & 94 & $18.80 \%$ \\
\hline $36-60$ & 156 & $31.20 \%$ \\
\hline $60-75$ & 188 & $37.60 \%$ \\
\hline Above 75 years & 62 & $12.40 \%$ \\
\hline \multicolumn{3}{|l|}{ Sex } \\
\hline Male & 282 & $56.40 \%$ \\
\hline Female & 218 & $43.60 \%$ \\
\hline \multicolumn{3}{|l|}{ Marital Status } \\
\hline Married & 232 & $46.40 \%$ \\
\hline Single & 144 & $28.80 \%$ \\
\hline Widowed & 68 & $13.60 \%$ \\
\hline Divorced & 56 & $11.20 \%$ \\
\hline \multicolumn{3}{|l|}{ Employment Status } \\
\hline Professional & 98 & $19.60 \%$ \\
\hline Civil Servants & 181 & $36.20 \%$ \\
\hline Sales Girls/Food Seller/Labourer & 85 & $17.00 \%$ \\
\hline No Job & 136 & $27.20 \%$ \\
\hline \multicolumn{3}{|l|}{ Educational Status } \\
\hline No Education & 68 & $13.60 \%$ \\
\hline Primary School & 121 & $24.20 \%$ \\
\hline Post Secondary & 142 & $28.40 \%$ \\
\hline University Degree & 169 & $33.80 \%$ \\
\hline
\end{tabular}

respondents are mostly civil servants and public servants (working in FCT) and closely followed by business owners (traders, contractors, and self-employed individuals) while $27.20 \%$ are jobless.

The result of the educational status also shows that $33.80 \%$ of the respondents have university degree and $28.40 \%$ have secondary and post-secondary education. $13.60 \%$ of the respondents have no education while 24.20 have primary education but those with no education have one skill or more. The result observes that family sizes of the respondent differ for the married ones. The result reveals that $30 \%$ of the family have 1 to 5 members size and $45 \%$ have 6 to 10 family size, while $25 \%$ have family sizes of above 10 members (Figure 3 ).

The result further discloses that the houses are built with mud (47\%), wood (15\%), Zinc (16\%) and Brick/ block (22\%) (Figure 4). However, the result reveals that the buildings within the settlement are not standard and the required basic housing facilities are not found. Some of the houses were not accessible 


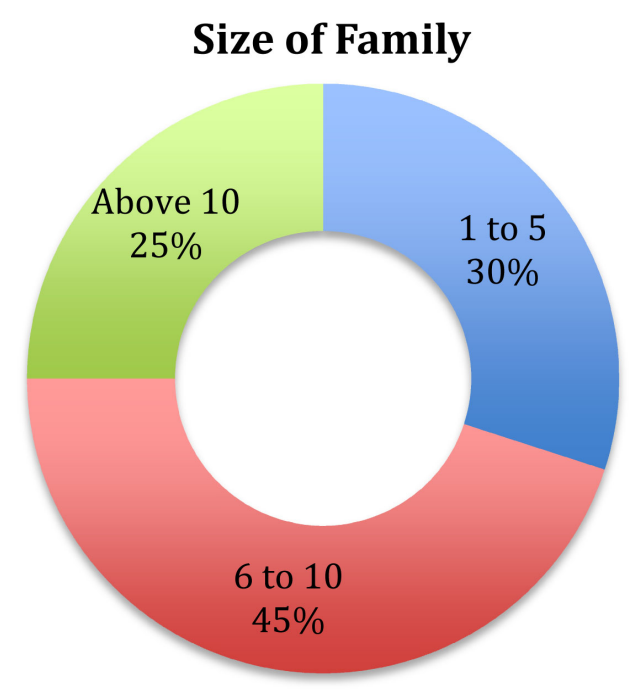

Figure 3. Size of family.

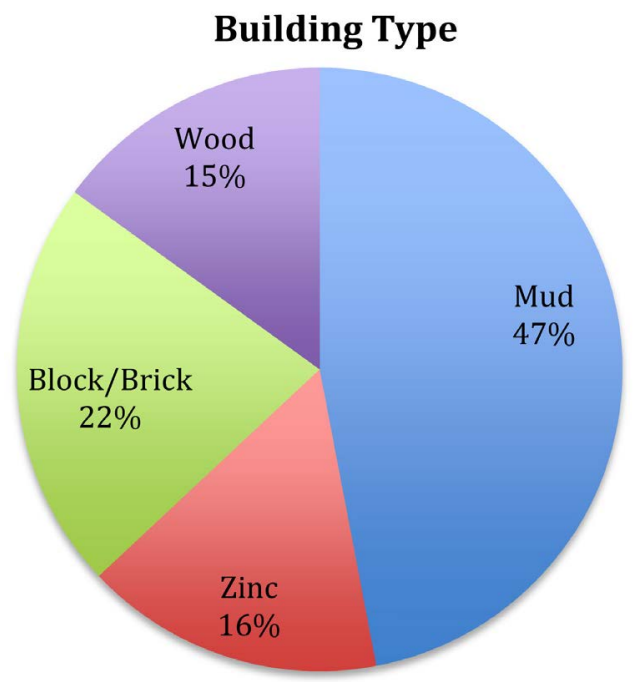

Figure 4. Building type.

and does not have linkage from the road as agreed by $65 \%$ of the respondents, who said that provision access road is not possible within the settlement.

The result also shows that $34 \%$ of the respondents live in one bedroom sharing common toilet and kitchen with other tenants, while 30\% live in two bedrooms apartments sharing common toilet and kitchen. In addition, the result shows that $21 \%$ of the respondents live in one bedroom with self-contained toilet and kitchen, and $15 \%$ of the respondents live in two bedrooms with self-contained toilet and kitchen (Figure 5). This implies that the families are living in very tight houses with little or no space for children to play within the houses. A further probe also shows that some family members sleep outside due to heat and space.

The result shows that the $91 \%$ occupants are tenants while $9 \%$ are landlords. On further probe, the respondents revealed that they are aware land fraudsters 


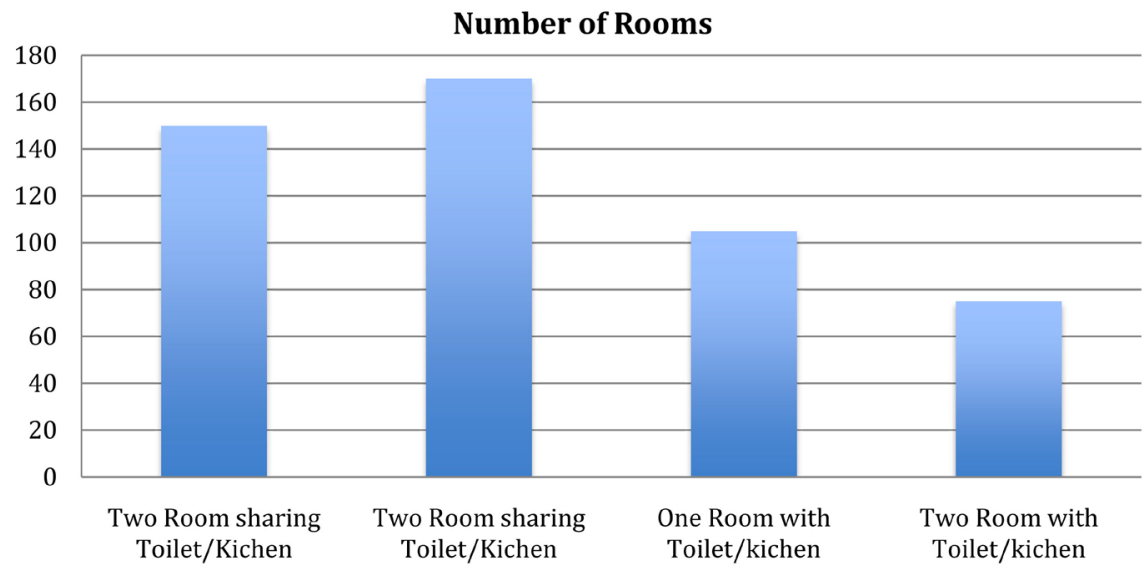

Figure 5. Number of room.

and that the land ownership procedures and processes are not clear. However, the result reveals that $77.77 \%$ of the house owners have land title issued by the Karu Local Government Authority (Table 3). The respondents were questioned on the affordability of rent in the settlement, of which $35 \%$ agreed that the rents are affordable while $65 \%$ disagreed. These respondents stated that the facilities are not standard and most houses have inadequate numbers of windows and access. The result reveals that $80 \%$ of the respondent has access to toilet and $20 \%$ have no toilet. The result additional shows that $68 \%$ of the houses have pit larine and were shared by the occupants of the houses. The result also exposes that $19 \%$ of the houses have water system toilet which are most in self-contained apartments within the settlement.

A further probe reveals that most of these house (52\% were built in the last 25 years. Furthermore, $13 \%$ of the houses do not have any form of toilet, thus the occupants defecate in the nearby open bushes as shown in Figure 6 .

The field survey revealed that $90 \%$ of the households are connected to public electricity (Power Holding Company of Nigeria) and 10\% are not. The respondents also disagreed that the power supply to the settlement is very low and the settlement sometimes stays without power for over weeks. $25 \%$ of the household heads agreed to know and understand waste disposal processes within the locality while $75 \%$ disagreed that there exists no waste disposal policy or framework. The $91.6 \%$ of the respondents refused that there is no environmental agency carrying out waste disposal within the settlement, while only $8.4 \%$ agreed that some Local government environmental agency do come two to three in a year. The survey revealed $89 \%$ of the respondents have waste bin in their houses and $11 \%$ do not. The survey further revealed that $45 \%$ of the respondents dump waste into the gutters around their houses and 55\% dump at a common waste point. However, further survey revealed that $13.4 \%$ of the respondents agreed that there are drainages around their houses while $86.67 \%$ disagreed as shown in Table 3. Further probe revealed that $81.4 \%$ knows that implication of bad waste disposal to health and $18.6 \%$ disagreed. 


\section{Toilet Type}

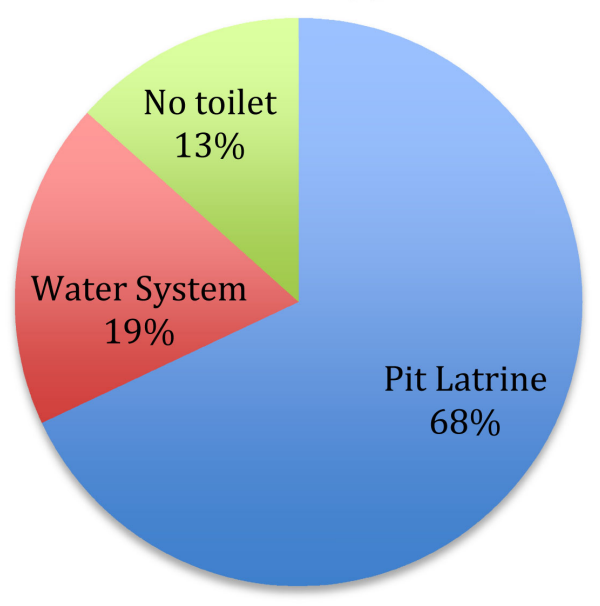

Figure 6. Toilet type.

Table 3. Result of survey questions.

\begin{tabular}{clcc}
\hline S/no & \multicolumn{1}{c}{ Question } & \multicolumn{1}{c}{ Yes } & \multicolumn{1}{c}{ No } \\
\hline 1 & Are you the owner of where you are living? & $45(9 \%)$ & $455(91 \%)$ \\
2 & If Yes, do you have title over the land? & $35(7 \%)$ & $465(93 \%)$ \\
3 & If No, how is your rent affordable? & $175(35 \%)$ & $325(65 \%)$ \\
4 & Do you have Toilet? & $400(80 \%)$ & $100(20 \%)$ \\
5 & Does your house have its source of water? & $204(72.85 \%)$ & $76(27.15 \%)$ \\
6 & Is your house connected to the Electricity & $450(90 \%)$ & $50(10 \%)$ \\
7 & Are you well Informed about waste disposal? & $125(25 \%)$ & $375(75 \%)$ \\
8 & Do the Environmental Agency carry out them & $42(8.4 \%)$ & $458(91.6 \%)$ \\
9 & waste as When Due? & $445(89 \%)$ & $55(11 \%)$ \\
10 & Do you have waste bin in your house? & $225(45 \%)$ & $275(55 \%)$ \\
11 & Are there drainages around your house? & $67(13.4 \%)$ & $433(86.67 \%)$ \\
12 & Are you aware of the health effect of poor waste disposal? & $407(81.4 \%)$ & $93(18.6 \%)$ \\
\hline
\end{tabular}

\section{Conclusion}

This study has shown that the basic social facilities needed to making life better do not exist in New Karu District. Therefore, one can easily deduce that the Karu LGA and Nassarawa State Government did not provide the infrastructures and facilities required to improve the well being of the residents of New Karu. The findings of this study confirmed that there exist high levels of inadequacies of infrastructure causes the environmental and living conditions. The study therefore recommends as a matter of policy that the FCTA and Nasarawa State Government should create Joint development Planning Authority. This will help to ensure improvement in the living conditions of poor people living in slums and provided with basic social facilities. 


\section{Conflicts of Interest}

The authors declare no conflicts of interest regarding the publication of this paper.

\section{References}

[1] United Nations Centre for Human Settlements (UN-Habitat) (2012) Nigeria: Karu Urban Profile. United Nations Human Settlement Programme Publications, Nairobi.

[2] Falade, J.B. and Aribigbola, A. (2010) Rapid Urban Sector Profiling for Sustainability Studies (Rusps) in Developing Countries. Implications for Urban Planning in Ondo State, Nigeria. Theoretical and Empirical Researches in Urban Management Number 5 (14).

[3] United Nations Centre for Human Settlements (UN-Habitat) (2003) The Challenge of Slums: Global Report on Human Settlement. Earth Scan, London.

[4] Okoye, T. (1990) Historical Development of Nigerian Housing Policies with Special Reference to Hosuing the Urban Poor. In: Amis, P. and Liyod, P., eds., Housing African's Urban Poor, University Press, Manchester, 73-85. https://doi.org/10.4324/9780429445132-4

[5] Durand Lasserve, A. (1996) Regularization and Integration of Irregular Settlements: Lessons from Experience UNDP/UNCHS (Habitat) World Bank Urban Management and Land. Working Paper No. 6, 94 p. http://www.iiste.org

[6] Aydemir, S. (1999) Kentsel Alanlarin Planlanmasi ve Tasarimi. KTU Yayini, Trabzon.

[7] Udeh, A.U. (2010) Impact of Development of the Federal Capital City, Abuja on Selected Settlements in Karu Local Government Area, Nasarawa State, Nigeria.

[8] United Nations Centre for Human Settlements (UN-Habitat) (2010).

[9] United Nations (2019) World Population Prospects 2019 Highlights. Department of Economic and Social Affairs Population Division, UN, New York.

[10] United Nations Centre for Human Settlements (UN-Habitat) (2007).

[11] Imman, A.B., Mohammed, B., Wilson, D.C. and Cheeseman, R. (2008) Solid Waste Management in Abuja, Nigeria. Waste Management, 28, 468-472.

https://doi.org/10.1016/j.wasman.2007.01.006

[12] Ezeamaka, C.K. (2015) Land Administration in Abuja, the Federal Capital City of Nigeria from 1999 to 2010. An Unpublished M.Sc. Dissertation, Department of Goegraphy, Nigerian Defence Academy, Kaduna.

[13] Butu, A.W., Ageda, B.R. and Bichi, A.A. (2013) Environmental Impacts of Roadside Disposal of Municipal Solid Wastes in Karu, Nasarawa State, Nigeria. International Journal of Environment and Pollution Research, 1, 1-9.

[14] Ayoade, A.A., Olurotimi, K. and Babatunde, A. A. (2012) Slum Development in 3rd World Countries: Causes, Effect and Way Out. A Case Study of Ibadan South East Local Government, Nigeria. 4th West Africa Built Environment Research Conference, Abuja, 24-26 July 2012, 91-98.

[15] Hir, J. (2012) The Tedious Task of Cleaning up Karu. Daily Trust Newspaper, Thursday 9 August.

[16] Dawam, P.D. (2000) The Geography of Abuja Federal Capital Territory. Famous/Asanlu Publishers, Minna.

[17] Federal Republic of Nigeria (2009) Legal Notice on Publication of 2006 Census Fi- 
nal Results.

[18] Report Firschman, P. (2001) Preliminary Master Plan Report Final Version of Greater Karu Urban Area, Nasarawa State Nigeria.

[19] Nassarawa State Ministry of Lands and Survey (2016) Map of Nasarawa State Map, Nassarawa State. 